\title{
GHG diffuse emissions estimation, and energy security to ENSO using MERRA-2 for largely hydroelectricity-based system
}

\author{
Estimación de emisiones difusas de GEl, y seguridad energética ligada al Fenomeno del Niño \\ utilizando MERRA-2 para sistemas basados en hidrogeneración
}

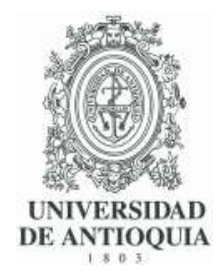

\begin{abstract}
Harold David Cuadros Tejeda (1) ', Yohen Cuellar (1) ', J. S. Chiriví Salomón ${ }^{1}$, Marco Guevara ${ }^{1} 2^{*}$
${ }^{1}$ Conservación, Bioprospección y Desarrollo Sostenible (COBIDES), Escuela de Ciencias Agricolas, Pecuarias y del Medio Ambiente (ECAPMA), Universidad Nacional Abierta y a Distancia. Calle 14 Sur \# 14 - 23. C. P. 3443700. Bogotá, Colombia.

${ }^{2}$ GICA-Grupo de Investigación de Calidad del Aire, Departamento de Ingeniería Química y Ambiental, Universidad Nacional de Colombia. Calle 44 \# 45-67. C. P. 111321. Bogotá, Colombia.
\end{abstract}

\section{ARTICLE INFO: \\ Received: February 20, 2019}

Accepted: April 03, 2019

\section{AVAILABLE ONLINE:}

April 04, 2019

Energy supply, energy development, emission factor, air pollution, hydropower desarrollo energético, factor de emisión, contaminación atmosférica, hidrogeneración

\section{KEYWORDS:}

suministro de energía,

ABSTRACT: In Colombia, hydropower share was $70 \%$ of the total installed capacity and more than $50 \%$ of the monthly generation share in 2015 , which coincided with the strongest $\mathrm{El}$ Niño Southern Oscillation (ENSO) phenomenon reported in the region. ENSO has been recognized as an influential climate pattern on meteorological variables. The generation via hydropower implies the construction of dams and water reservoirs; these flooded areas generate an important amount of Green House Gases (GHG). In this regard, the main aim of this research was to quantify the diffusing emissions of $\mathrm{CO}_{2}$ and $\mathrm{CH}_{4}$ in the flooded areas of the main hydroelectric power generation facilities in Colombia. GHG emissions were calculated by the implementation of an IPCC methodology. The obtained results show that more than $1,042,500$ t $\mathrm{CO}_{2}$-Eq (i.e. $\mathrm{CO}_{2}$ and $\mathrm{CH}_{4}$ ) are emitted in Colombia per year from this source, representing $4.4 \%$ of the total $G H G$ emissions in the country. As the second aim, the vulnerability of Colombia's energy independence, in terms of power supply to ENSO and climate change was analyzed using the MERRA-2 dataset from NASA, for the years between 2010 and 2017.

RESUMEN: En Colombia, la participación de la energía hidroeléctrica fue del $70 \%$ de la capacidad instalada y más del $50 \%$ de la participación de la generación en 2015, lo que coincidió con el más fuerte Fenómeno del Niño reportado históricamente en la región. El Fenómeno del Niño ha sido reconocido como un patrón climático influyente en las variables meteorológicas. La generación a través de hidroelectricidad implica la construcción de represas de agua; estas superficies inundadas generan emisiones importantes de Gases de efecto invernadero (GEI). El objetivo principal de esta investigación es cuantificar las emisiones de $\mathrm{CO}_{2}$ y $\mathrm{CH}_{4}$ en las áreas inundadas del país. Las emisiones de GEI se calcularon mediante la implementación de una metodología del IPCC. Los resultados obtenidos muestran que esta fuente emite más de 1,042,500 t de $\mathrm{CO}_{2}$-Eq les decir, $\mathrm{CO}_{2}$ y $\mathrm{CH}_{4}$ ) en Colombia, lo que representa el $4.4 \%$ del total de emisiones de $\mathrm{GEl}$ en el país. Como segundo objetivo, se analizó la vulnerabilidad de la independencia energética de Colombia, en términos de suministro de energía durante periodos de Fenómeno del Niño y cambio climático, utilizando los datos del modelo MERRA-2 de la NASA para los años entre 2010 y 2017.

\begin{tabular}{lll}
\hline Symbol & Term & Units SI \\
\hline $\mathrm{A}$ & Area & $\mathrm{m}^{2}$ \\
$\mathrm{~V}$ & Volume & $\mathrm{m}^{3}$ \\
$\mathrm{~W}$ & Watt & $\mathrm{J} / \mathrm{s}$ \\
$\mathrm{Gg}$ & Gigagram & $109 \mathrm{~g}$ \\
$\mathrm{t}$ & Tone & $106 \mathrm{~g}$ \\
\hline
\end{tabular}

* Corresponding author: Marco Guevara

E-mail: maguevaraldaunal.edu.co

ISSN 0120-6230

e-ISSN 2422-2844

\begin{tabular}{cc}
\hline Abbreviation & Term \\
\hline GHG & Green House Gases \\
$\mathrm{CO} 2$ & Carbon Dioxide \\
$\mathrm{CH} 4$ & Methane \\
$\mathrm{CO} 2-\mathrm{Eq}$ & Equivalent Carbon Dioxide \\
$\mathrm{OM}$ & Organic Matter \\
$\mathrm{EF}$ & Emission Factor \\
$\mathrm{SIN}$ & Sistema Interconectado Nacional \\
& (National Interconnected System) \\
\hline
\end{tabular}

DOI: 10.17533/udea.redin.n91a07 


\section{Introduction}

In Colombia, $70 \%$ of the electricity is generated by hydropower plants located along the mountains of the country (Figure 1). This share will increase in the next years with the estimated internal energy demand, aiming to use the big power potential of the country. Accordingly, the construction of new hydropower plants is planned by the government [1, 2]. Even though the electricity generation has been historically supplied by hydropower, there is $30 \%$ of the energy mix produced by thermoelectric plants, which use coal, natural gas, and other fossil fuels. Furthermore, during the strongest El Niño Southern Oscillation (ENSO) phenomenon reported, the one that occurred in 2015, the electricity produced by hydropower plants reached $50 \%$ of contribution in the national generation mix [3], evidencing an important vulnerability to the climate change. This situation led to water-resource cutoffs in many cities and towns along the country.

The dams required by the hydroelectric power plants are built to contain the water reservoirs based on flooded areas [4], which are mainly located in tropical mountain forests in Colombia [5]. The water reservoirs based on flooded areas in tropical weather have been recently studied for the purpose of estimating their environmental impact based on the Green House Gases (GHG) diffuse emissions to the atmosphere [6-10]. The share of hydropower in the Latin American countries such as Ecuador is about $40 \%$, which is a lower percentage in comparison with the share in Colombia [8, 11, 12]. This circumstance became an important case of study for strategic energy planning in Colombia [13].

ENSO is recognized as an influential climate pattern on meteorological variables such as global solar radiation, wind speed, and precipitation rates, affecting directly the hydropower supply $[14,15]$. Colombia, as a dependent country on hydroelectric power generation technologies, is sensitive to climate change [13]. This strong dependency makes climate change an issue to be included in the development plan of the country. Because of this, ENSO phenomenon has been analyzed during the last years in order to determine the sensitivity of the country to global warming [16-20]. Subsequently, the main aim of this research is to quantify the diffusing emissions of $\mathrm{CO}_{2}$ and $\mathrm{CH}_{4}$ in the reservoirs corresponding to flooded areas located in the main hydroelectric power facilities in Colombia. To achieve this, we first summarized the energy production by technology in terms of the available installed capacity. Then, the IPCC methodology for diffusing GHG emissions calculation was implemented over the flooded areas in each of the listed hydropower facilities [21, 22]. As for last consideration, the dependency analysis of the country energy generation to ENSO was performed using data from the MERRA-2 dataset from NASA for the years of 2014 to 2017 [5, 23-26]

Table 1 Mean monthly generation per technology type in Colombia 2015 year [3]

\begin{tabular}{lll}
\hline Technology & Generation, GWh & Share, \% \\
\hline Diesel & 259.77 & 4.55 \\
Hydroelectric & $2,906.03$ & 50.95 \\
Co-generation & 50.12 & 0.88 \\
Coal & 737.37 & 12.93 \\
Oil & 111.10 & 1.95 \\
Gas & $1,419.62$ & 24.89 \\
Jet-A1 & 0.00 & 0.00 \\
Gas-Coal Mixture & 0.00 & 0.00 \\
Kerosene & 17.14 & 0.30 \\
Small Hydroelectric & 150.31 & 2.64 \\
Small Gas & 45.76 & 0.80 \\
Wind & 6.67 & 0.12 \\
Solar & 0.00 & 0.00 \\
TOTAL & $5,703.88$ & 100.00 \\
\hline
\end{tabular}

Table 2 Installed capacity per Technology type in Colombia 2015 year [3]

\begin{tabular}{lll}
\hline Technology & Power, MW & Share, \% \\
\hline Hydraulic & $11,500.50$ & 69.97 \\
Thermal gas & $1,619.50$ & 9.85 \\
Thermal coal & $1,348.40$ & 8.20 \\
Liquids & $1,92.00$ & 9.69 \\
Gas-Liquids & 264.00 & 1.61 \\
Wind & 18.40 & 0.11 \\
Biomass & 93.20 & 0.57 \\
Solar & 0.00 & 0.00 \\
Total & 16.436 .00 & 100.00 \\
\hline
\end{tabular}

\section{Materials and methods}

\subsection{Energy Generation in Colombia}

The energy generation infrastructure in Colombia consists of different technologies, which are operating under the total installed capacity. This current situation represents the reference for the comparison between technologies and their impact on the national GHG emissions to the atmosphere. The mean monthly energy production in Colombia is presented based on the data of energy production during the year 2015 (Table 1). The installed capacity by technology in Colombia is shown (Table 2) to assess the distribution of available infrastructure in the country, which is compared with the monthly energy production previously described. 


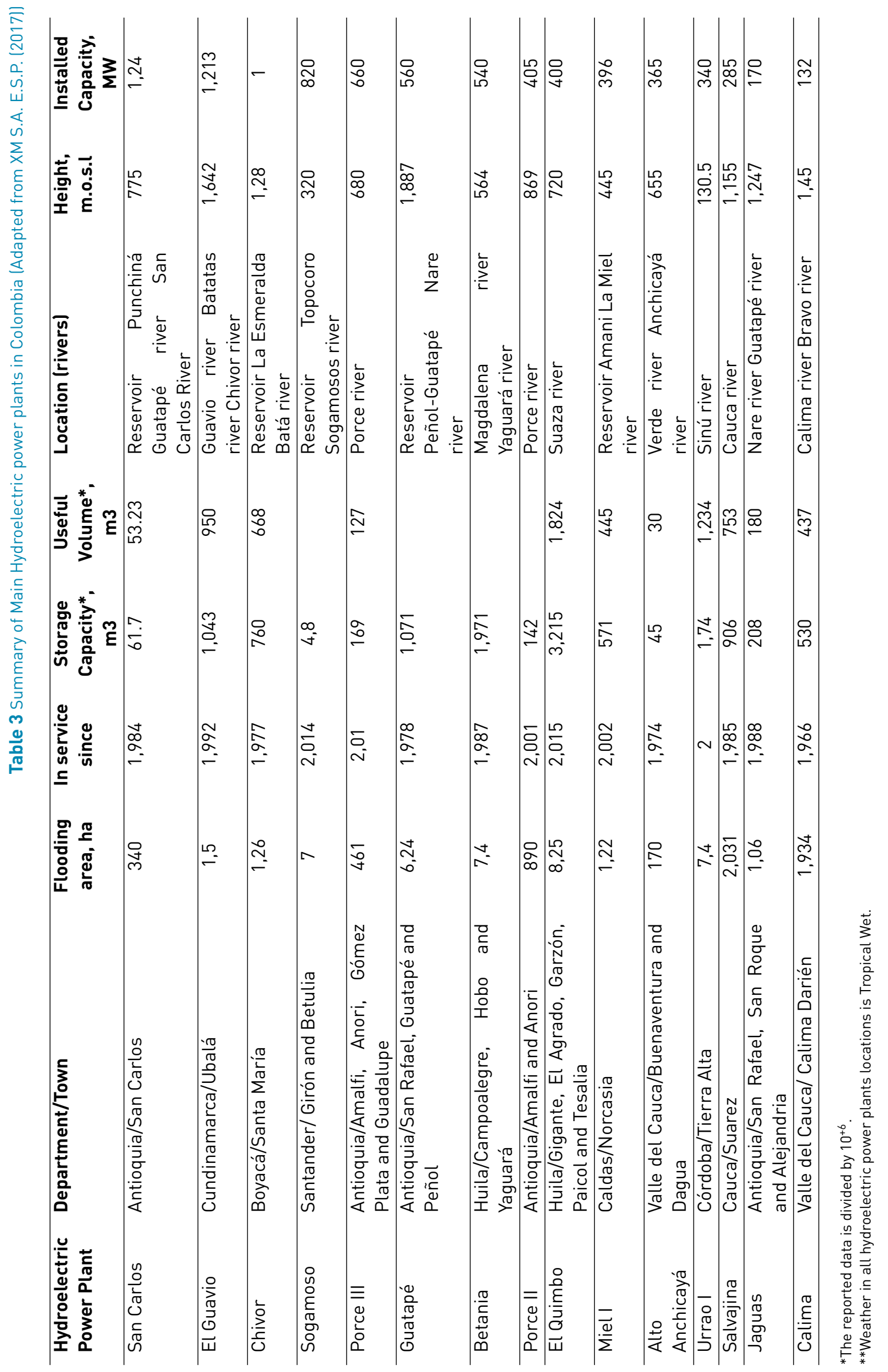


The amount of energy generated achieves 5,703.88 GWh per month in the country. The hydroelectric has the biggest share of the energy mix in the country, even during the year 2015 when the strongest ENSO phenomenon was reported, which affects the generation performance due to the low level in water reservoirs. Nevertheless, the national energy demand increases from 3.9 to $4.4 \%$ by year [2], showing the situation above as an important risk for the national energetic security in the country [13].

\subsection{Studied power plants}

In this research, the main hydroelectric power plants in Colombia were considered as the hydropower facilities with the biggest flooded areas associated with their operation (Table 3, Figure 1). Table 3 summarizes the main hydroelectric power plants in the country. Data about the flooded area and reservoir capacity were detailed for GHG diffuse emissions calculations, which are described in the next sections.

\subsection{MERRA-2 datasets}

MERRA-2 is a dataset which contains results of simulations developed by NASA that hosts meteorological variables along the globe with a spatial resolution of $0.5^{\circ} \times 0.625^{\circ}(55.5 \mathrm{~km} \times 69.375 \mathrm{~km})$ [26]. This dataset incorporates observation types not available for its predecessor and includes updates to the Goddard Earth Observing System (GEOS) model and an analysis scheme to offer an advanced product suite suitable for the weather and climate applications. The M2TINXFLX v5.12.4 variable (or Total Surface Precipitation) and M2IMNXLFO v5.12.4 variable (Surface Air Temperature) were used for the sensitivity to climate change analysis. Data were retrieved from the online platform GIOVANNI from NASA $[23,24,27,28]$.

\subsection{Methodology}

The methodology implemented in the calculation of diffusing $\mathrm{GHG}$ emissions, $\mathrm{CO}_{2}$, and $\mathrm{CH}_{4}$, from the main hydroelectric power plants in Colombia, was based on the following equations (Equation (1) and Equation 2) [21] and measures (Table 4 and 5):

Method for $\mathrm{CO}_{2}$ :

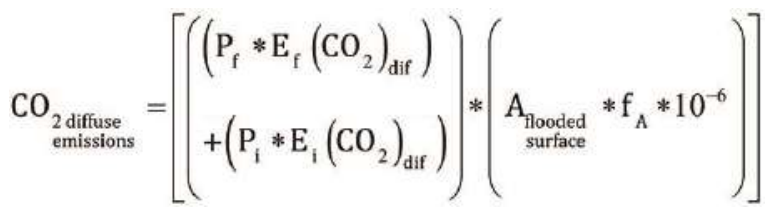

Where:

$$
\begin{aligned}
& \mathrm{CO}_{2} \text { diffuse emissions }=\text { total emissions of } \mathrm{CO}_{2} \text { from } \\
& \text { flooded areas, } \mathrm{Gg} \mathrm{CO}_{2} \text { year }^{-1} \text {. } \\
& P_{f}=\text { ice-free period, days year }{ }^{-1} \\
& P_{i}=\text { period with ice, days year }{ }^{-1} \text { (not } \\
& \text { applicable over Colombial. } \\
& E_{f}\left(C_{2}\right)_{d i f}=\text { Daily average of diffuse } \\
& \text { emissions from the air-water } \\
& \text { interface during the ice-free } \\
& \text { period, } \mathrm{kg} C \mathrm{CO}_{2} \mathrm{ha}^{-1} \text { day }^{-1} \text {. } \\
& E_{i}\left(\mathrm{CO}_{2}\right)_{\text {dif }}=\text { Diffuse emissions related to } \\
& \text { the ice-covered period, } \mathrm{kg} \mathrm{CO}_{2} \\
& \mathrm{ha}^{-1} \text { day }^{-1} \text {. } \\
& A_{\text {flooded surface }}=\text { Total surface area of the } \\
& \text { reservoir, including flooded } \\
& \text { lands, lakes and rivers, ha. } \\
& f_{A}=\text { Fraction of the total area } \\
& \text { of the reservoir that was } \\
& \text { flooded in the last } 10 \text { years, } \\
& \text { dimensionless. }
\end{aligned}
$$

\begin{tabular}{|c|c|c|c|c|c|}
\hline \multirow[t]{2}{*}{ Weather } & \multicolumn{5}{|c|}{$\begin{array}{l}\text { Diffuse emissions (lce free period) } \\
\mathrm{Ef}\left(\mathrm{CO}_{2}\right)_{\text {dif }}\left(\mathrm{kg} \text {. de } \mathrm{CO}_{2} \mathrm{ha}^{-1} \mathrm{day}^{-1}\right)^{*}\end{array}$} \\
\hline & Median & Min. & Max. & $\mathbf{N}_{\mathrm{m}}$ & $\mathbf{N}_{\text {res }}$ \\
\hline $\begin{array}{l}\text { Polar / Boreal } \\
\text { very wet }\end{array}$ & 11.8 & 0.8 & 34.5 & 1,011 & 20 \\
\hline $\begin{array}{l}\text { Medium cold, } \\
\text { wet. }\end{array}$ & 15.2 & 4.5 & 86.3 & 633 & 20 \\
\hline $\begin{array}{l}\text { Medium } \\
\text { warm, wet. }\end{array}$ & 8.1 & -10.3 & 57.5 & 507 & 33 \\
\hline $\begin{array}{l}\text { Medium } \\
\text { warm, dry. }\end{array}$ & 5.2 & -12.0 & 31.0 & 390 & 43 \\
\hline $\begin{array}{l}\text { Tropical, very } \\
\text { wet. }\end{array}$ & 44.9 & 11.5 & 90.9 & 642 & 7 \\
\hline Tropical, dry. & 39.1 & 11.7 & 58.7 & 197 & 5 \\
\hline
\end{tabular}

Method for $\mathrm{CH}_{4}$ :

Table 4 Measured $\mathrm{CO}_{2}$ emissions from flooded [21]

*The values in the second column represent the means of $\mathrm{CO}_{2}$ emissions, which correspond to the arithmetic means of the flows measured on the individual reservoirs. The Min and Max values correspond to the lowest and the highest of all the individual measurements within a given climatic region; they are given only as an indicator of the variability $\mathrm{Nm}$ = a number of measurements; Nres = number of reservoirs sampled. These measures may include non-anthropogenic emissions le.g., Emissions from carbon in the upstream basin) and possible double counts of anthropogenic emissions (e.g., wastewater from urban areas of the reservoir region) and thus may overestimate emissions [21].

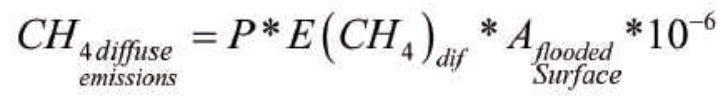



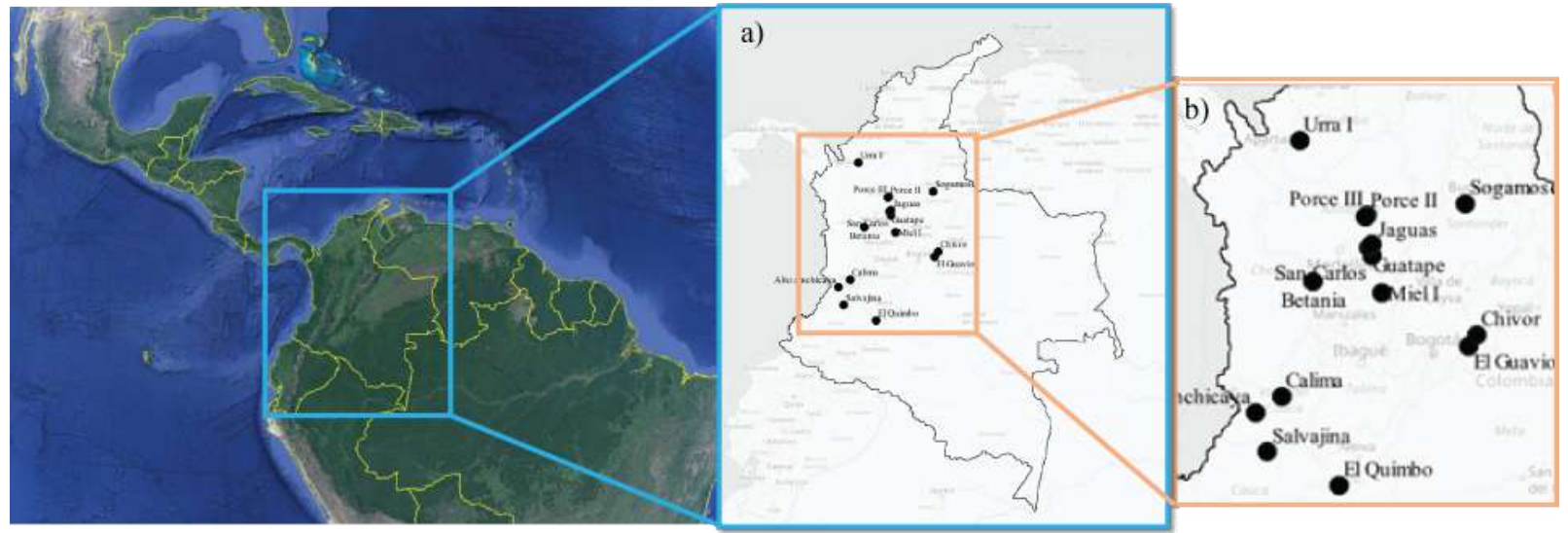

Figure 1 Main hydroelectric power plants in Colombia: a) General map of Colombia, b) Detailed area of hydroelectric potential in the Colombian Andes Mountains. (Source: This study)

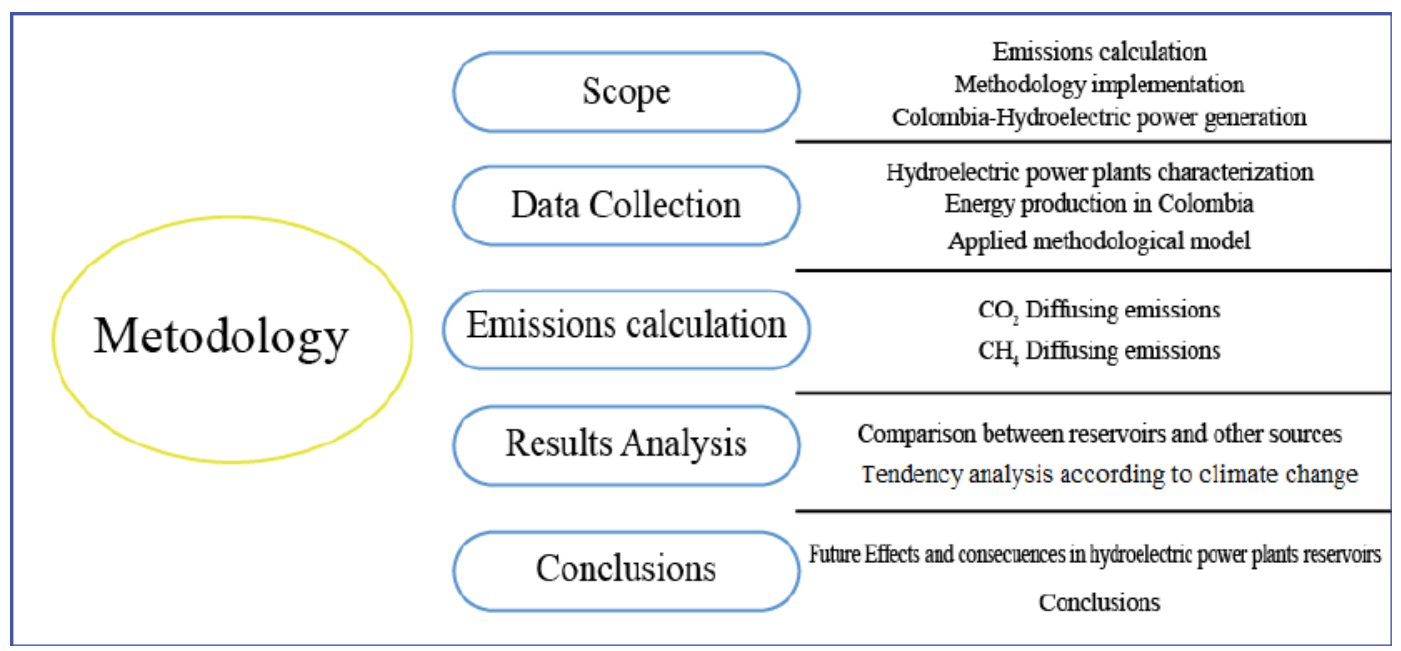

Figure 2 Methodological scheme for calculation and analysis of diffuse emissions of GHG from hydroelectric reservoirs (Source:

Where:

$$
\begin{aligned}
\mathrm{CH}_{4 \text { diffuse emissions }=} \begin{array}{l}
\text { total diffuse emissions of } \\
\mathrm{CH}_{4} \text { from flooded areas, } \mathrm{Gg}
\end{array} \\
\mathrm{CH}=\begin{array}{l}
\text { period with ice, days year } \\
\text { per } \\
\text { (notapplicable in Colombial. }
\end{array} \\
\text { daily mean diffuse } \\
\text { emissions, } \mathrm{kg} \mathrm{CH}_{4} \mathrm{ha}^{-1} \\
\text { day }{ }^{-1} . \\
\text { total area of the flooded } \\
\text { area, including flooded } \\
\text { lands, lakes and rivers, ha. }
\end{aligned}
$$

of the scope founded on available information to generate a new one. The analysis consisted of the comparison with other types of generation technologies using different resources available in the country. An analysis of the main disadvantages of the hydropower generation technology in the tropical areas during the effects of ENSO phenomenon was also performed $[13,29]$. This last aspect results to be important in the energy development planning of the country, the intermittency in the resource affects directly the rate of energy production in a stable way. The effect of this situation is rapidly increasing, leading to critical and unsustainable the energy production in the near future, mainly driven by the global warming and the increasing demand for energy.

The methodology used for this calculation of GHG from water reservoirs in hydropower plants consists of the scheme (Figure 2), which is deeply related with the inductive approach, taking as starting point the definition 
Table 5 Measured $\mathrm{CH} 4$ from flooded land [21, 22]

\begin{tabular}{|c|c|c|c|c|c|}
\hline \multirow[t]{2}{*}{ Weather } & \multicolumn{5}{|c|}{$\begin{array}{l}\text { Diffuse emissions (lce free period) } \\
\mathrm{Ef}\left(\mathrm{CO}_{2}\right)_{\text {dif }}\left(\mathrm{kg} . \text { de } \mathrm{CO}_{2} \mathrm{ha}^{-1} \text { day }^{-1}\right) *\end{array}$} \\
\hline & Median & Min. & Max. & $\mathbf{N}_{\mathrm{m}}$ & $\mathbf{N}_{\text {res }}$ \\
\hline $\begin{array}{l}\text { Polar / Boreal } \\
\text { very wet }\end{array}$ & 11.8 & 0.8 & 34.5 & 1,011 & 20 \\
\hline $\begin{array}{l}\text { Medium cold, } \\
\text { wet. }\end{array}$ & 15.2 & 4.5 & 86.3 & 633 & 20 \\
\hline $\begin{array}{l}\text { Medium } \\
\text { warm, wet. }\end{array}$ & 8.1 & -10.3 & 57.5 & 507 & 33 \\
\hline $\begin{array}{l}\text { Medium } \\
\text { warm, dry. }\end{array}$ & 5.2 & -12.0 & 31.0 & 390 & 43 \\
\hline $\begin{array}{l}\text { Tropical, very } \\
\text { wet. }\end{array}$ & 44.9 & 11.5 & 90.9 & 642 & 7 \\
\hline Tropical, dry. & 39.1 & 11.7 & 58.7 & 197 & 5 \\
\hline
\end{tabular}

*Same as table 4.

\section{Results and discussion}

\subsection{Calculation of diffuse emissions for the San Carlos hydroelectric power plant}

The data for the water reservoir in San Carlos hydroelectric power plant was obtained (Table 6). This input data was required for the calculation of $\mathrm{GHG}$ diffuse emissions. Carbon dioxide and methane were calculated for the main hydroelectric power plants in Colombia using this approach, only the calculation for San Carlos plant was documented as a detailed example, but the results are presented for all the plants involved in this research (Table 7).

Table 6 General data extracted for reservoir Punchiná - San Carlos (Source: This Study)

\begin{tabular}{lcc}
\hline Variable & Magnitude & Units \\
\hline Weather & Tropical wet & - \\
$E_{f}\left(\mathrm{CO}_{2}\right)_{d i f}$ & 44.90 & $\mathrm{kgCO}_{2} \mathrm{ha}^{-1} \mathrm{day}^{-1}$ \\
$E\left(\mathrm{CH}_{4}\right)_{\text {dif }}$ & 0.63 & $\mathrm{kgCH} \mathrm{CH}_{4}^{-1} \mathrm{day}^{-1}$ \\
Free Ice period & 365.00 & days \\
Flooded Area & 340.00 & ha \\
In service Since & 1984.00 & - \\
Flooded fraction & 1.00 & - \\
of total area & & \\
\hline
\end{tabular}

Calculation of $\mathrm{CO}_{2}$ diffuse emissions for the San Carlos hydroelectric power plant

Using the equations: Equation (1) for $\mathrm{CO}_{2}$. The diffuse emissions are computed according to Equation (3), Equation (4) and Equation (5):

$$
\left.\mathrm{CO}_{2} \text { emissions }=\left[\left(\begin{array}{l}
365 \text { days year } \\
* 44.9 \mathrm{~kg} \mathrm{CO}_{2} \mathrm{ha}^{-1} \text { day }^{-1}
\end{array}\right)+(0)\right) *\left(340 * 1 * 10^{-6}\right)\right]
$$

$\mathrm{CO}_{2}$ emissions $=\left[\begin{array}{l}\left(16388.5 \mathrm{~kg} \mathrm{CO}_{2} \mathrm{ha}^{-1} \text { year }^{-1}\right) \\ *\left(3.4 * 10^{-4} \mathrm{ha}\right)\end{array}\right]$

$$
\mathrm{CO}_{2} \text { emissions }=5.6 \mathrm{GgCO}_{2} \text { year }^{-1}
$$

Calculation of $\mathrm{CH}_{4}$ diffuse emissions for the San Carlos hydroelectric power plant

Using the equations: Equation (2) for $\mathrm{CH}_{4}$. The diffuse emissions are computed according to Equation (6) and Equation (7): in a similar way as $\mathrm{CO}_{2}$ in the section above.

$$
\begin{array}{r}
\mathrm{CH}_{4} \text { Emissions }=365 \text { day year }{ }^{-1} \\
* 0,630 \mathrm{kgCH}_{4} \mathrm{ha}^{-1} \mathrm{day}^{-1} * 340 \mathrm{ha} * 10^{-6} \\
\mathrm{CH}_{4} \text { Emissions }=0.08 \mathrm{GgCH}_{4} \text { year }^{-1}
\end{array}
$$

\subsection{Calculation of diffuse emissions for all the main hydroelectric power plants in Colombia}

This section summarizes the results of the calculation shown in detail in the last section, in this case for all the hydroelectric power plants in this research. The results in terms of each $\mathrm{GHG}$, i.e. $\mathrm{CO}_{2}$ and $\mathrm{CH}_{4}$, are shown, as well as their equal in $\mathrm{CO}_{2}$ for the $\mathrm{CH}_{4}$, and the total emissions of both pollutants (Table 7).

\subsection{Comparison of diffuse emissions between hydroelectric power plants and other available resources in Colombia}

The total emissions and power generation rates were compared with the generation of other resources available in Colombia (Table 8, Figure 3). From these data, we remarked that hydropower is the resource that generates less GHG emissions per MWh produced, due to a large amount of hydropower production activities in the country. The total emissions from hydropower are larger than the sugar cane residues or kerosene burning for energy generation purposes.

Regarding the total emissions from other resources, the full amount of energy generation in 2015 was 38,938,000 MWh, to produce this amount of energy $23,458,556 \mathrm{t}$ $\mathrm{CO}_{2}$-Eq year ${ }^{-1}$ were emitted to the atmosphere (Table 9). 
Table $7 \mathrm{CO}_{2}$ and $\mathrm{CH}_{4}$ diffusing emissions for main hydroelectric power plants in Colombia (Source: This study)

\begin{tabular}{|c|c|c|c|c|c|}
\hline $\begin{array}{l}\text { Hydroelectric } \\
\text { power plant }\end{array}$ & $\begin{array}{l}\text { Energy } \\
\text { generation, } \\
\text { GWh }\end{array}$ & $\begin{array}{l}\mathrm{CO}_{2} \\
\text { Emissions, } \\
\mathrm{Gg}_{\text {year }}{ }^{-1}\end{array}$ & $\begin{array}{l}\mathrm{CH}_{4} \\
\text { Emissions, } \\
\mathrm{Gg} \text { year }^{-1}\end{array}$ & $\begin{array}{l}\mathrm{CH}_{4} \\
\text { Emissions } \\
\text { in terms of } \\
\mathrm{CO}_{2-\mathrm{Eq}} \quad \mathrm{Gg} \\
\text { year-1 }^{-1}\end{array}$ & $\begin{array}{l}\mathrm{CO}_{2-\mathrm{Eq}} \text { Total } \\
\text { emissions, } \\
\text { Gg year }^{-1}\end{array}$ \\
\hline San Carlos & 6,020 & 5.6 & 0.08 & 2.00 & 7.60 \\
\hline El Guavio & 5,700 & 24.6 & 0.34 & 8.50 & 33.10 \\
\hline Chivor & 3,626 & 20.6 & 0.28 & 7.00 & 27.60 \\
\hline Sogamoso & 5,056 & 114.7 & 1.60 & 40.00 & 154.70 \\
\hline Porce III & 3,605 & 7.6 & 0.11 & 2.75 & 10.35 \\
\hline Guatapé & 1,945 & 102.3 & 1.40 & 35.00 & 137.30 \\
\hline Betania & 2,304 & 121.3 & 1.70 & 42.50 & 163.80 \\
\hline Porce II & 1,294 & 14.6 & 0.20 & 5.00 & 19.60 \\
\hline El Quimbo & 2,216 & 135.2 & 1.90 & 47.50 & 182.70 \\
\hline Miel I & 1,460 & 20.0 & 0.28 & 7.00 & 27.00 \\
\hline Alto Anchicayá & 2,291 & 2.8 & 0.04 & 1.00 & 3.80 \\
\hline Urra I & 1,421 & 121.3 & 1.70 & 42.50 & 163.80 \\
\hline Salvajina & 1,050 & 33.3 & 0.47 & 11.75 & 45.05 \\
\hline Jaguas & 770 & 17.4 & 0.24 & 6.00 & 23.40 \\
\hline Calima & 180 & 31.7 & 0.44 & 11.00 & 42.70 \\
\hline TOTAL & 38,938 & 773.0 & 10.78 & 269.50 & $1,042.50$ \\
\hline
\end{tabular}

Table $8 \mathrm{CO}_{2}$-Eq GHG Emissions from different types of energy generation[3]

\begin{tabular}{lrrc}
\hline Resource & Generated energy, $\mathbf{M W h}$ & $\begin{array}{r}\text { Total emissions, } \\
\mathbf{t} \mathbf{~ C O}_{2-\mathrm{Eq}} \text { year }^{-1}\end{array}$ & $\begin{array}{r}\text { Emission Factor (EF), } \\
\mathbf{t} \mathbf{C O}_{\mathbf{2 - E q}} / \mathbf{M W h}\end{array}$ \\
\hline Water & $38,938,000$ & $1,042,500.00$ & 0.03 \\
Diesel & $3,117,240$ & $10,500,081.36$ & 3.40 \\
Sugar cane residues & 601,440 & $376,606.32$ & 0.63 \\
Coal & $8,848,440$ & $8,211,919.20$ & 1.00 \\
Fuel-oil & $1,333,200$ & $3,175,320.72$ & 2.40 \\
Gas & $17,035,440$ & $1,102,604.16$ & 0.10 \\
Kerosene & 205,680 & $92,024.52$ & 0.45 \\
\hline
\end{tabular}

The hydropower is $50.95 \%$ of the total energy generation during 2015, a low value considering the installed capacity is about $70 \%$ (Table 2). In terms of GHG emissions, the 4.4 $\%$ of the GHG were emitted from hydropower generation during 2015.

\subsection{Uncertainty Analysis}

The uncertainty of the used method for $\mathrm{CH}_{4}$ and $\mathrm{CO}_{2}$ is mainly affected by two aspects: emission factors, and the estimation of the flooded area [21, 32].

According to the input data used for this study, the emission factors vary between 1 and 2 orders of magnitude depending on the reservoir location, and selection of the emission factor. This corresponds to relatively high uncertainty, and the obtained results are perhaps an overestimation. For this study, we consider the location of the reservoirs and their size according to official data, based on this, we assume the emission factor vary with 1 order of magnitude in the worst case.

In terms of flooded areas estimations, the data is accurate with a range of $10 \%$ for flooded areas larger than $100 \mathrm{~km}^{2}$. For the flooded areas with less than $100 \mathrm{~km}^{2}$, the range of accuracy may vary from 10 to $50 \%[21]$. For this study, the data was taken from official sources, according to this, we assume the accuracy of the data about the flooded areas is $\pm 25 \%$.

In this case, the best scenario in terms of error is $\pm 10 \%$ in the flooded area values, and 1 order of magnitude variation in the emission factors. The worst-case scenario, in terms of error, is $\pm 25 \%$ in the flooded area values, and 1 order of magnitude variation in the emission factors. 


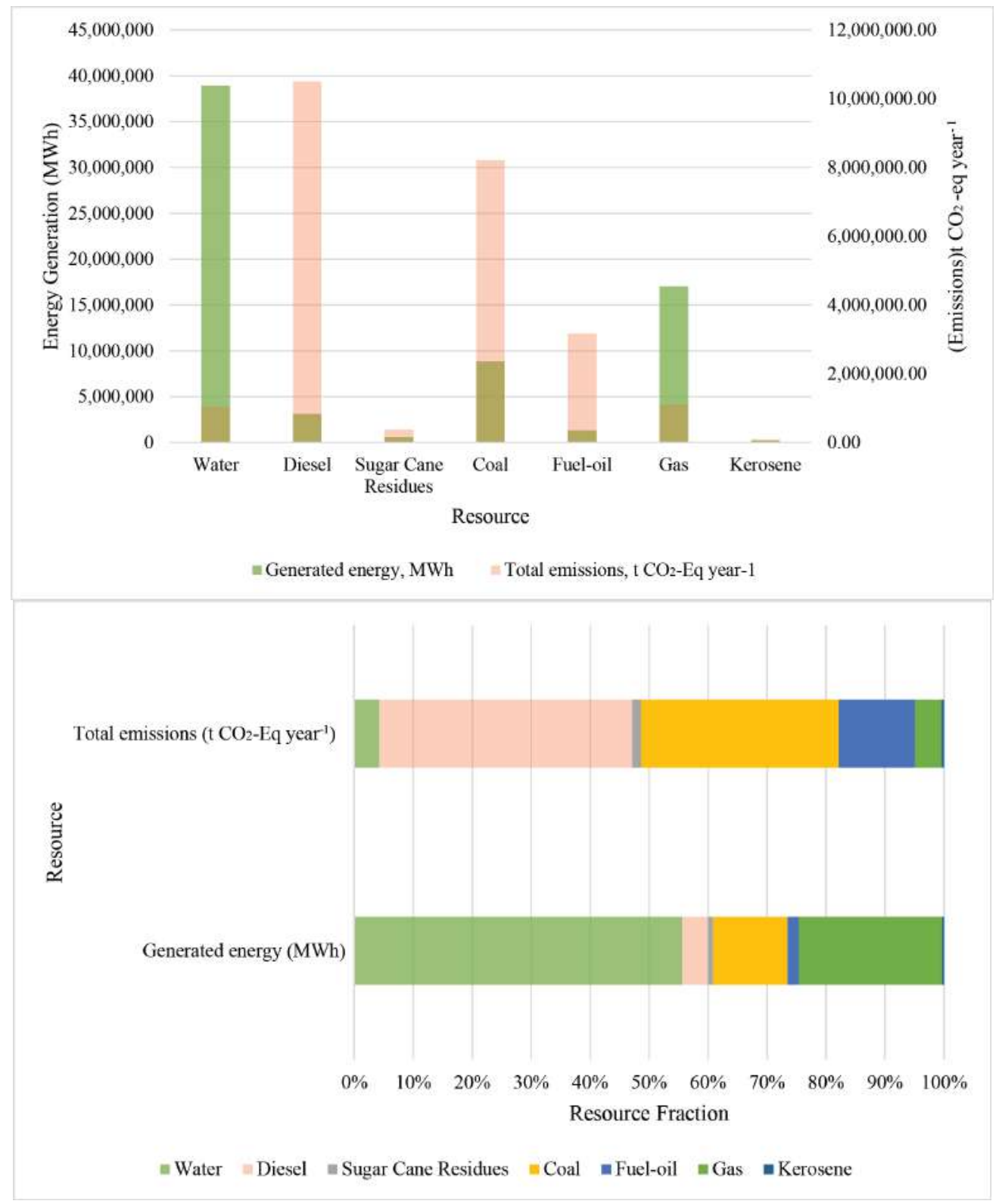

Figure 3 Generated energy and GHG emissions for each energetic resource available in Colombia: a) Columns of emissions and energy generated by source, b) Participation of each source in the total energy generation and emissions. (Source: This Study)

Table 9 GHG emissions from hydroelectric reservoirs and energy production in Colombia [3, 30, 31]

\begin{tabular}{|c|c|c|c|}
\hline Segment of share & $\begin{array}{r}\text { Energy generation } \\
2015, \mathrm{MWh}\end{array}$ & $\begin{array}{r}\text { Total Emissions } \\
\text { per year, } \mathrm{t} \mathrm{CO}_{2}-\mathrm{Eq}_{\text {year }}{ }^{-1}\end{array}$ & $\begin{array}{r}\text { Emission Factor (EF), } \\
\mathrm{t} \mathrm{CO}_{2-\mathrm{Eq}} / \mathrm{MWh}\end{array}$ \\
\hline $\begin{array}{l}\text { Hydroelectric power plants } \\
\text { reservoirs in this research }\end{array}$ & $38,938,000.00$ & $1,042,500.00$ & 0.027 \\
\hline Full Colombian Energy production & $68,446,505.16$ & $23,458,556.28$ & 0.340 \\
\hline
\end{tabular}

3.5 Analysis of ENSO phenomenon effect on the hydropower generation in Colombia

Colombia is strongly affected by ENSO due to its geographical location [20]. Occurrences of ENSO have been more frequent, gradually stronger, and more severe over the last 20-30 years than they were during the preceding hundred years [33]. The recent years in Colombia have been characterized by an increase in the area averaged temperature [13]. The precipitation rates 
and surface temperature for Colombia, specifically in the region of -81.5625 long, -4.5703 lat, -64.6875 long, and 14.0625 lats (Figure 1), were retrieved for the years between 2010 and 2017 to graphically represent the effect of ENSO phenomenon that took place in 2015, and the climate change through these variables (Figure 4). The regions of the western Pacific presented the highest precipitation rates. The Sierra Nevada de Santa Marta and the eastern mountains also showed an important precipitation rate in the analysis domain: spatially and temporally [5]. The large red spot in the country map for the precipitation variable is located in the region with the biggest hydropower potential, where also coincided with most of the hydropower generation facilities (Figure 1).

In Colombia, the Andes mountains are divided into three big mountains ranges; called Western, Central and Eastern mountains ranges (Cordilleras Occidental, Central, and Oriental). These mountains have heights of thousands of M.A.S.L (Meters Above Sea Level). The higher mountain peaks are characterized by low temperatures, the cold areas which correspond to main mountains are represented by the MERRA-2 database (Figure 4). The hot-spots are mainly located in the oriental planes and Caribbean coast.

The 2010 year has been lately the year with the highest precipitation rates (Figure 4). This is explained by the area covered by stronger precipitations, which is larger in comparison to 2015 when the strongest ENSO phenomenon took place. In 2010, precipitations on the Eastern Mountain range and La Sierra Nevada de Santa Marta were registered, data is observed in the contour of Figure 4. Conversely in 2015, smaller precipitation rates were presented in the same areas indicating a reduction in the hydrologic resources available for energy production and other activities such as agriculture. ENSO phenomenon is also perceived by the temperature maps, in 2010 and 2017; during this period, both cold and hot years were clearly registered. Considering 2010 in comparison with 2015, the areas with temperatures above $30{ }^{\circ} \mathrm{C}$ are smaller.

According to MERRA-2 dataset, the year 2011 was the coldest year without any area (in the Colombian territory) with surface temperature values above $30^{\circ} \mathrm{C}$. Even so, after the year 2011, the temperature showed an increase until 2015. Figure 4 shows that the affected areas by ENSO are the northern Caribbean coast, in Colombia and Venezuela. After 2015, the temperature decrease gradually, and the precipitation increased according to the natural cycle of the tropical weather.

In order to quantitatively analyze the effect of ENSO macroscale phenomenon over Colombia, the internal energy demand and energy production by hydropower technology must be considered simultaneously with precipitation rates and temperature along the country. Figure 5 summarizes this data between the years 2010 and 2015 [2, 31, 34]. Figure 5-a compares the internal energy demand and production by hydropower technology against precipitation, showing the increasing demand and energy production in the same proportion along the 2010 to 2015 period. Meanwhile, the precipitation decreases in 2012, and again in 2015 to its lowest value. Figure 5-b shows the internal-national energy demand and energy production by hydropower technology with temperature, as mentioned above temperature has its lowest value in 2011. After this year, the surface temperature increases gradually until its highest value in 2015, according to the presence of the ENSO phenomenon in the region.

From Figure 5, energy production by hydropower has an increase in 2011, reaching the higher production value $(48,427,000 \mathrm{MWh})$, after this year the energy production decreased to 38,938,000 MWh (Table 8) in the year 2015. This gradually decreases between 2011 the coldest year and 2014 one year before ENSO (5,000,000 MWh). In 2015 , energy hydropower energy production decreases $9,036,300 \mathrm{MWh}$ (about $15 \%$ of the demand) evidencing a direct affectation of ENSO in the hydropower capacity of the country to meet the increasing demand. The energy demand tends to keep increasing, due to several aspects such as social and industrial development, population increasing, and now immigrants from Venezuela reaching one million new inhabitants in August 2018.

\subsection{Energy risk analysis}

Colombia has been historically affected by ENSO in the near past; diseases, drinking water supply, food and energy production have been sensitive points to this phenomenon. Based on the data collected from MERRA-2, and the increasing local demand (data plotted in Figure 5), it is possible to conclude that in the year 2015, characterized by strong ENSO in the region, the energy generated from water reservoirs, by hydropower plants, was not enough.

With the increasing demand, in part due to air conditioning requirements during hot seasons, ENSO produces a decrease in the water reservoir levels, leading to lac of energy supply. During the year 2015, the energy generated from hydroelectric resource was less than $50 \%$ of the installed capacity. The mean level in the water reservoirs was $65 \%$ of the total capacity of water storage. Additionally, during the last years, the thermoelectric generation systems have a deficit in the generation labout $70 \mathrm{GW}$ ), this deficit has been covered by hydropower systems. This situation leads to a more risky situation in 


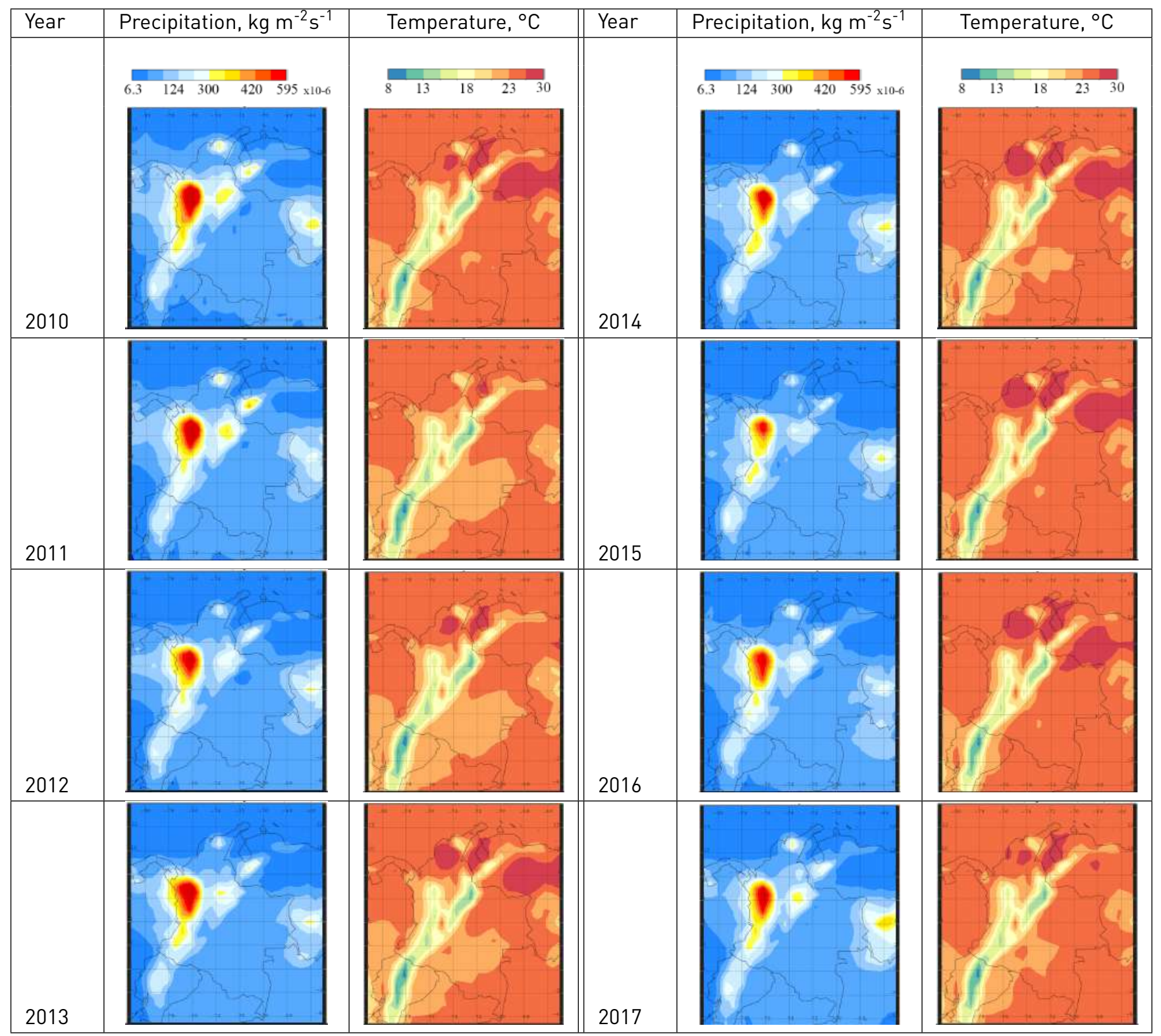

Figure 4 Yearly time averaged contours for Colombia during the time-period of 2010 to 2017. Variables: Total Surface Precipitation and Surface Air Temperature retrieved from NASA's MERRA-2 (Source: This study)

terms of National Energy Security.

In the year 1992, blackouts and hour change were implemented by the government to compensate the climate effects in the performance of energy infraestructure, even so, in 2015 these measures were not necessary. In the future with a suitable and sustainable energy development, the need of measures such as blackouts or hour changes will be less. This means the probability of undesirable events (blackouts, hour change, and curfew, among others) tend to be low. Based on the two last big affectations in the energy supply by the effect of climate, it is possible to estimate the probability of undesirable events: 25 to $30 \%$.

\section{Conclusions}

The methodology described by IPCC (2006) was implemented to calculate the GHG diffuse emissions from the hydroelectric power plants water reservoirs in Colombia. This calculation allowed the comparison of the GHG emissions from this energy source available in great quantities along the country of Colombia against other types of energy. The share of use of this energy source was more of $50 \%$ in the year 2015. The emission associated with this anthropological activity was estimated as $1,042,500.00 \mathrm{t} \mathrm{CO}_{2}$-Eq year ${ }^{-1}$. The impact of energy generation is lower than other energy production 


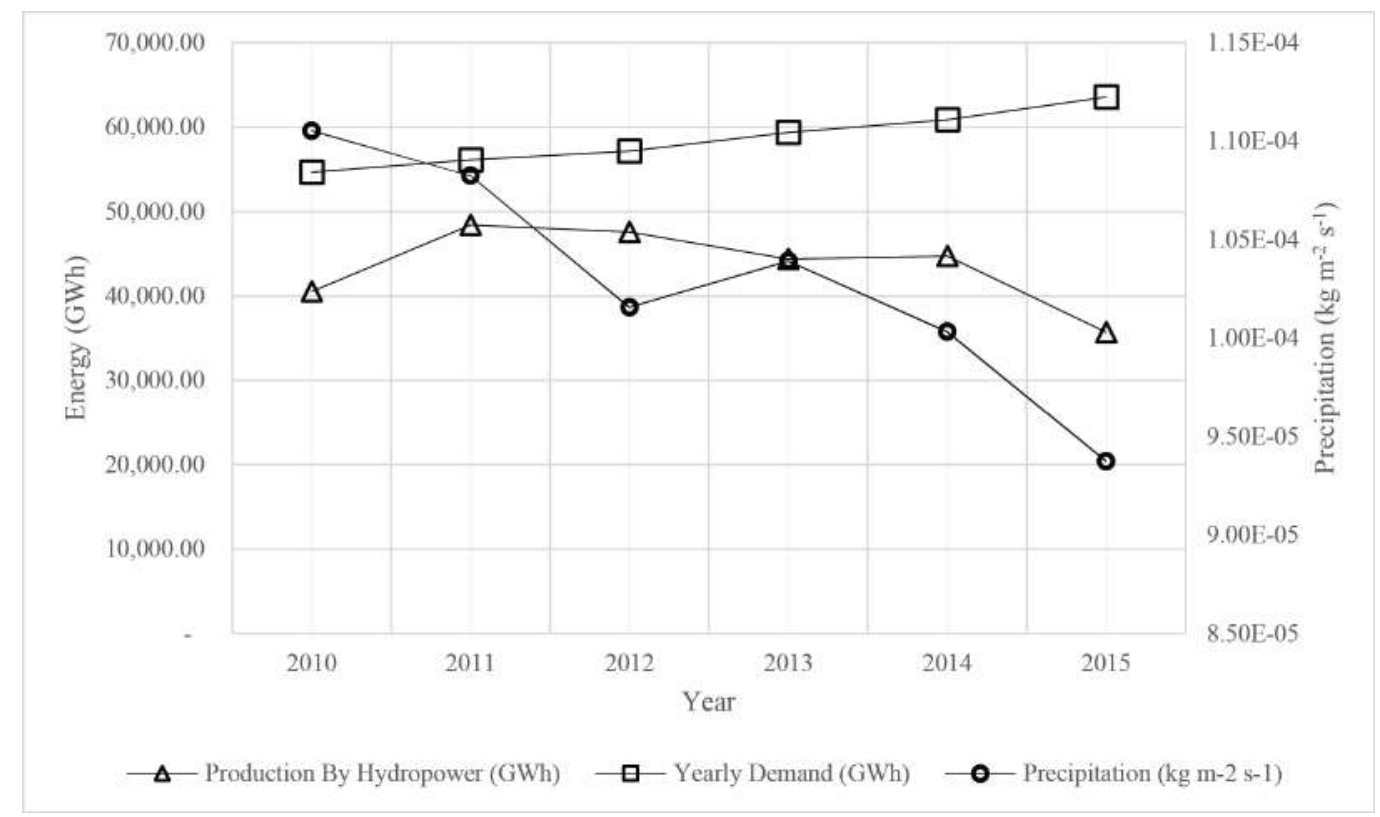

a)

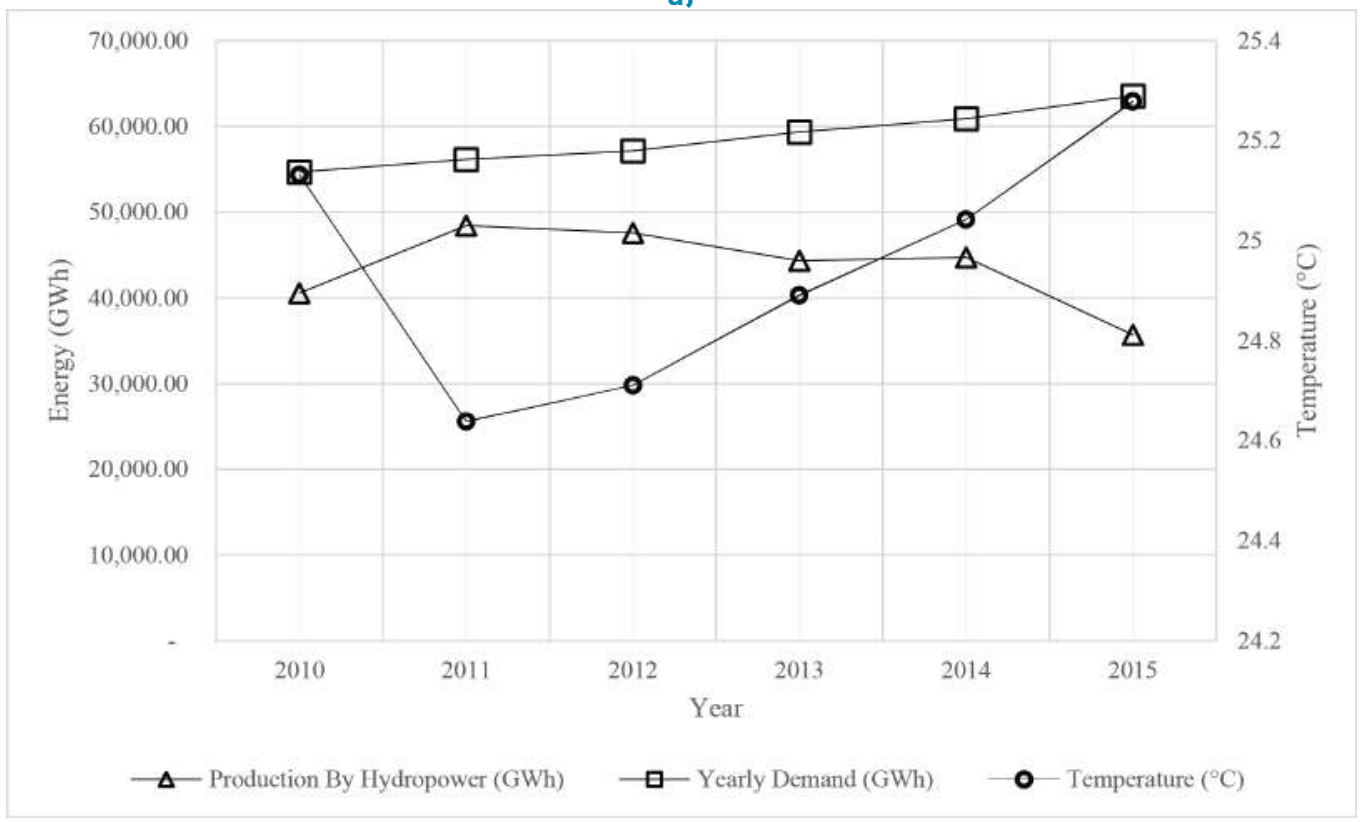

b)

Figure 5 Yearly time series for Colombia during the time-period of 2010 to 2015, includes data on Demand, Hydropower Production and: a) Total Surface Precipitation, and b) Surface Air Temperature (Source: This Study)

alternatives, where fossil fuels or mass burning are the technological basis. The Emission Factor (EF) was estimated for hydroelectric energy generation as $0.027 \mathrm{t}$ $\mathrm{CO}_{2}-\mathrm{Eq} / \mathrm{MWh}$. The results obtained show that flooding is an important source of $\mathrm{GHG}$ emissions to the atmosphere. The local effects in public health must be studied in detail in further works. Local communities not only will be exposed to higher GHG level when new projects of hydropower generation begin, but also the vital water resource for local communities will be affected.
Further analysis and exploration of this phenomena should be applied for the case of Colombia. More accurate modeling of the dispersion of $\mathrm{GHG}$ emitted from water reservoirs can be performed using CFD simulation. This is a more detailed microscale approach which can be implemented for future research. CFD technology due to its features can be applied to this complex not steady fluid flow phenomena, and quantitatively describe the receptors exposition in each particular location 
considering transport phenomena such as turbulence, mass, and heat transfer[35-40].

Infrastructure development will lead to challenges to meet the increasing regional demand. Such development must be performed considering important implications, in several aspects, to avoid issues like the one taking place in Cauca River, with the hydroelectric power plant construction of Hidroituango. Interconnection and new projects are required in the near future, not only hydropower based but solar and wind as well.

The high dependency on water reservoirs in Colombia to generate electricity represents a national issue, directly related to global change. ENSO phenomenon has led in the past years to reduce the energy production in the country, which affects the utility coverage, even in main cities such as Bogotá, Medellín, Cali or Bucaramanga.

In 2015, the hydropower generation decreased $9,036,300$ MWh (about $15 \%$ of the demand) evidencing a direct effect of ENSO on the hydropower capacity of the country to meet the increasing demand. This situation put in evidence the sub-utilization of the installed capacity during dry seasons and ENSO periods as a great weakness. With $70 \%$ of installed capacity for energy generation through hydropower plants, the year 2015 only $50 \%$ of the energy generation was achieved by hydropower technologies.

The last analysis leads to conclude that Colombia has an important national issue depending mainly on hydropower to meet the internal energy demand. Within the next years, the government must promote the development of energy production infrastructure, and interconnection, to ensure the energy required to meet the increasing demand in an actual context of development, increasing population and new immigrant's presence in the Colombian society. The development and upgrading of the energy infrastructure in Colombia must consider other clean technologies to take advantage of different renewable resources, such as wind and solar. The development plan of the country must be focused to achieve the best energy mix for the future through the implementation of optimization algorithms with energy planning as the main scope.

\section{Acknowledgments}

Authors would like to thank the companies Smart \& Simple Engineering S.A.S. (S\&SE S.A.S) and Symbiont Research \& Development Corporation S.A.S. for the technical support in the satellite datasets retrieval and analysis tools development, and style editing of this manuscript, respectively.

\section{References}

[1] (2018) Sistema de generación de energía de EPM. EPM. Accessed Jun. 05, 2018. [Online]. Available: https://bit.ly/2IGlzFl

[2] Unidad de planeación Minero Energética (UPME). (2015) Plan de expansión de referencia generación-transmisión 2014-2028. [Online]. Available: https://bit.ly/2Wb6pd1

[3] (2015) Boletín estadístico de minas y energía 2010-2015. Unidad de planeación Minero Energética (UPME). Accessed Jun. 10, 2018. [Online]. Available: https://bit.ly/2V3vXvW

[4] (2016) World energy resources: Hydropower. World Energy Council (WEC). Accessed Jan. 15, 2018. [Online]. Available: https://bit.ly/ 2dQ1pH3

[5] P. Muñoz and et al., “Holocene climatic variations in the Western Cordillera of Colombia: A multiproxy high-resolution record unravels the dual influence of ENSO and ITCZ," Quat. Sci. Rev., vol. 155, pp. 159-178, Jan. 2017.

[6] D. Weisser, "A guide to life-cycle greenhouse gas (GHG) emissions from electric supply technologies," Energy, vol. 32, no. 9, pp. 1543-1559, Sep. 2007.

[7] A. Tremblay, M. Lambert, and L. Gagnon, “Do hydroelectric reservoirs emit greenhouse gases?" Environ. Manage., vol. 33, pp. S509-S517, Jul. 2014.

[8] A. Briones, J. Uche, and A. Martínez, "Accounting for GHG net reservoir emissions of hydropower in Ecuador," Renew. Energy, vol. 112, pp. 209-221, Nov. 2017.

[9] A. Palau, M. Alonso, and D. Corregidor, “Análisis del ciclo de carbono en embalses y su posible efecto en el cambio climático. Aplicación al embalse de Susqueda (río Ter, NE España)," Ingeniería del Agua, vol. 17, no. 3, pp. 247-255, Sep. 2010.

[10] A. Palau and M. Alonso. (2008, Nov.) Embalses y cambio climático. Endesa. [Online]. Available: https://bit.ly/2HPuH9n

[11] M. A. Paucar, “Estudio de emisiones de metano producidas por embalses en centrales hidroeléctricas en Ecuador," M.S. thesis, Pontificia Universidad Católica de Chile, Santiago, Chile, 2014.

[12] V. Martínez and O. L. Castillo, “The political ecology of hydropower: Social justice and conflict in Colombian hydroelectricity development," Energy Res. Soc. Sci., vol. 22, pp. 69-78, Dec. 2016.

[13] S. Zapata, M. Castaneda, E. Garces, C. J. Franco, and I. Dyner, "Assessing security of supply in a largely hydroelectricity-based system: The Colombian case," Energy, vol. 156, pp. 444-457, Aug. 2018.

[14] K. Mohammadi and N. Goudarzi, "Study of inter-correlations of solar radiation, wind speed and precipitation under the influence of $\mathrm{El}$ Niño Southern Oscillation (ENSO) in California," Renew. Energy, pp. 190-200, May 2018.

[15] K. S. Boodoo, M. E. McClain, J. J. Vélez, and O. L. Ocampo, “Impacts of implementation of Colombian environmental flow methodologies on the flow regime and hydropower production of the Chinchiná River, Colombia," Ecohydrol. Hydrobiol., vol. 14, no. 4, pp. 267-284, 2014.

[16] M. Detto, S. J. Wright, O. Calderón, and H. C. Muller, “Resource acquisition and reproductive strategies of tropical forest in response to the El Niño-Southern Oscillation," Nat. Commun., vol. 9, no. 1, pp. 1-8, Mar. 2018.

[17] B. Ayarzagüena, S. Ineson, N. J. Dunstone, M. P. Baldwin, and A. A. Scaife, "Intraseasonal effects of El Niño-Southern Oscillation on North Atlantic climate," J. Clim., vol. 31, no. 21, pp. 1-35, Aug. 2018.

[18] J. S. Mantilla, L. I. Moncada, N. E. Matta, and P. H. Adler, “Distribution of black flies (Diptera: Simuliidae) along an elevational gradient in the Andes Mountains of Colombia during the El Niño Southern Oscillation," Acta Trop., vol. 183, pp. 162-172, 2018.

[19] L. C. Pérez and P. Molnar, "Sea surface temperatures in the Eastern Equatorial Pacific and surface temperatures in the Eastern Cordillera of Colombia during El Niño: Implications for pliocene conditions," Paleoceanography, vol. 32, no. 11, pp. 1309-1314, Nov. 2017.

[20] S. C. Smith and D. Ubilava, “The El Niño Southern Oscillation and 
economic growth in the developing world," Glob. Environ. Chang., vol. 45, pp. 151-164, Jul. 2017.

[21] Apéndice 2 Enfoque posible para estimar las emisiones de $\mathrm{CO}_{2}$ provenientes de las tierras convertidas en tierras permanentemente inundadas: Base para su futuro desarrollo metodológico, Directrices del IPCC de 2006 para los inventarios nacionales de gases de efecto invernadero, Grupo Intergubernamental de Expertos sobre el Cambio Climático, Hayama, Japan, 2006.

[22] Apéndice 3 Emisiones de $\mathrm{CH}_{4}$ provenientes de tierras inundadas: Base para su futuro desarrollo metodológico, Directrices del IPCC de 2006 para los inventarios nacionales de gases de efecto invernadero, Grupo Intergubernamental de Expertos sobre el Cambio Climático, Hayama, Japan, 2006.

[23] Giovanni. NASA. Accessed Oct. 16, 2017. [Online]. Available: https://go.nasa.gov/2YsJRqp

[24] M. A. Guevara, A. Guevara, J. F. Méndez, and L. C. Belalcázar, “Spatial and temporal assessment of particulate matter using AOD data from MODIS and surface measurements in the ambient air of Colombia," Asian J. Atmos. Environ., vol. 12, no. 2, pp. 165-177, Jul. 2018.

[25] PARATEC, “Capacidad efectiva por tipo de generación," PARATEC, Medellín, Colombia, Tech. Rep., Mar. 2017.

[26] Merra-2. NASA. Accessed Sep. 03, 2018. [Online]. Available: https://go.nasa.gov/2TGAAr5

[27] (2016) Earth observatory. NASA. Accessed Jun. 20, 2018. [Online]. Available: https://go.nasa.gov/2iELmOe

[28] S. Kang and J. B. Ahn, "Global energy and water balances in the latest reanalyses," Asia-Pacific J. Atmos. Sci., vol. 51, no. 4, pp. 293-302, Nov. 2015.

[29] F. Almeida and et al., "How much is enough? an integrated examination of energy security, economic growth and climate change related to hydropower expansion in Brazil," Renew. Sustain. Energy Rev., vol. 53, pp. 1132-1136, Jan. 2016.

[30] UPME-base de datos de embalses. UPME. Accessed Apr. 28, 2018. [Online]. Available: https://bit.ly/2uzFjRg
[31] (2015) Informe de oferta y generación. XM S.A. E.S.P. [Online]. Available: https://bit.ly/2DkQH8j

[32] J. C. Jenkins, H. D. Gonzo, and S. Ogle, "Other lands," Institute for Global Environmental Strategies, Hayama, Japan, Tech. Rep., 2006.

[33] J. L. da Silva and M. A. Vasconcelos, "Amazon and the expansion of hydropower in Brazil: Vulnerability, impacts and possibilities for adaptation to global climate change," Renew. Sustain. Energy Rev., vol. 15, no. 6, pp. 3165-3177, Aug. 2011.

[34] Unidad de planeación Minero Energética (UPME). (2013, Mar.) Proyección de demanda de energía eléctrica en colombia. [Online]. Available: https://bit.ly/2UFRfjL

[35] J. S. Riaño, M. A. Guevara, and L. C. Belalcázar, "CFD modeling and evaluation of a bi-stable micro-diverter valve," Ciencia, Tecnol. y Futur., vol. 8, no. 1, pp. 77-84, 2018.

[36] M. A. Guevara, J. D. Reyes, and F. A. Guevara, “Diseño y evaluación de un ciclón para separación de sólidos y gas de una corriente con un flujo multifásico empleando dinámica de fluidos computacional," Rev. VirtualPro, vol. 166, pp. 1-30, 2015.

[37] C. Gorlé, J. van Beeck, P. Rambaud, and G. V. Tendeloo, “CFD modelling of small particle dispersion: The influence of the turbulence kinetic energy in the atmospheric boundary layer," Atmos. Environ., vol. 43, no. 3, pp. 673-681, Jan. 2009.

[38] F. Li, E. S. Lee, J. Liu, and Y. Zhu, "Predicting self-pollution inside school buses using a CFD and multi-zone coupled model," Atmos. Environ., vol. 107, pp. 16-23, Apr. 2015.

[39] Y. Tominaga and T. Stathopoulos, "CFD modeling of pollution dispersion in building array: Evaluation of turbulent scalar flux modeling in RANS model using LES results," J. Wind Eng. Ind. Aerodyn., vol. 104-106, pp. 484-491, May 2012.

[40] M. A. Guevara and L. C. Belalcazar, "NGL supersonic separator: modeling, improvement, and validation and adjustment of $k$-epsilon RNG modified for swirl flow turbulence model," Revista Facultad de Ingeniería Universidad de Antioquia, no. 82, pp. 82-93, Feb. 2017. 